\title{
Community Contribution towards Conservation of Tropical Fruit Trees in Malaysia
}

\author{
I. Salma1, U. Shariah"2, B. Pearlycia², W. W. Wong'3 , A. Shukor ${ }^{4}$, H. Norhayati5, \\ N. A. Noor Camellia ${ }^{*}$ \\ ${ }^{1}$ Strategic Resource Research Centre, MARDI Headquarters, Persiaran MARDI-UPM, Serdang, Selangor, Malaysia \\ ${ }^{2}$ Agriculture Research Centre Semongok, Kuching, Sarawak, Malaysia \\ ${ }^{3}$ Agriculture Research Centre Tuaran, Department of Agriculture Sabah, Tuaran, Sabah, Malaysia \\ ${ }^{4}$ Department of Agriculture, Alor Star, Kedah, Malaysia \\ ${ }^{5}$ Department of Agriculture Titi Gantong, Perak, Malaysia \\ Email: ${ }^{\text {camellia dbest@yahoo.com }}$
}

Received 28 December 2014; accepted 15 January 2015; published 21 January 2015

Copyright (C) 2015 by authors and OALib.

This work is licensed under the Creative Commons Attribution International License (CC BY).

http://creativecommons.org/licenses/by/4.0/

(c) (i) Open Access

\begin{abstract}
Community participation in the conservation of tropical fruit trees is one approach taken by the Tropical Fruit Trees Project funded by UNEP/GEF carried out at six sites in Malaysia. Three conservation approaches were implemented at the sites that are diversity block, heritage block and common block. A total of $\mathbf{1 5 5 0}$ fruit trees mainly from the genera Mangifera, Garcinia and Nephelium were planted. At Kampung Kakeng, Serian, Sarawak a 5 ha diversity block was established. 110 fruit trees comprising species from the genera Mangifera, Nephelium, Garcinia, Durio, Artocarpus, Anonna, and Musa were planted in the diveristy block. An orchard consisting of many species of old fruit trees at Sibuti was identified as a Heritage Block for conservation and education purposes. A Mangifera pentandra tree aged more than 100 years from the Heritage Block was used as a source of seeds for new plantings. While in Kota Belud, a few binjai (Mangifera caesia) trees 50 100 years old were labelled as heritage fruit trees for public awareness as well as for conservation in the Heritage block. At other sites Yan, Papar and Bukit Gantang, fruit trees within the genus Mangifera, Garcinia and Nephelium were planted in the homegardens, orchards and public places such as playground compounds or near riversides.
\end{abstract}

\section{Keywords}

Farmers, Indigenous, Forest, Traditional Knowledge, Rural, Diversity

Subject Areas: Agricultural Science, Conservation Biology, Information Science, Sociology

\footnotetext{
${ }^{*}$ Corresponding author.

How to cite this paper: Salma, I., Shariah, U., Pearlycia, B., Wong, W.W., Shukor, A., Norhayati, H. and Noor Camellia, N.A. (2015) Community Contribution towards Conservation of Tropical Fruit Trees in Malaysia. Open Access Library Journal, 2: e1146. http://dx.doi.org/10.4236/oalib.1101146
} 


\section{Introduction}

Wild and cultivated fruit species diversity in Asia are being threatened due to deforestation, rapid agricultural development and industrialization accompanied by other social and cultural pressures. According to a new global forest map, Malaysia had the world's highest rate of forest loss between 2000 and 2012 [1]. This scenario has built an alarm for conservation programs to be taken seriously by government and community.

Mostly neglected, tropical fruit trees have received attention in recent years due to their significant role as source of various nutrients, food security, agro-food industries, and income generation [2]. Indigenous tropical fruit species are very important for the economic welfare of small farmers in rural area. Most of these species have multipurpose use such as medicine, timber, food colouring agents and shelter. The cultivation and maintenance of fruit tree species can provide highly sustainable production systems that conserve soils, microenvironments and biodiversity [2].

Networks of small home gardens in the larger ecosystem provide a wide range of options for food security and source of new planting material. Farming with perennial fruit trees such as mango, mangosteen, durian and rambutan, which are seasonal in fruiting, complements household food supply. The off-season allows farmers to plant short term or non-seasonal crops and rear bees or maintains livestock for their income [3].

Therefore, efforts to conserve these fruit genetic resources $e x$-situ have been carried out by several government agencies including Malaysian Agricultural Research and Development Institute (MARDI). Ex-situ conservation is the process of protecting an endangered species of plant by removing it from an unsafe or threatened habitat and placing it or part of it under the care of humans [4]. Ex-situ conservation in the field genebanks requires large space, high maintenance and the trees are susceptible to abiotic and biotic stress. The development of in-situ methods can maintain populations in surroundings to ensure the processes of evolution and adaptation within their environments. In Nigeria, the community farmers contribute in fruit trees conservation by adopted tree domestication, increasing their skills in fruit trees management, established community nurseries and conserved the economic fruit trees in rural communities [4].

Most funded project in Malaysia also are not designed with the involvement of local communities. Under the Tropical Fruit Trees Project funded by UNEP/GEF carried out at six sites in Malaysia, various types of conservation were identified and being participated by the communities at the sites. The objective of this project was to enhance germplasm conservation through participation of local communities and other stakeholders.

\section{Methodology}

\subsection{Study Sites}

The five years GEF UNEP project "Conservation and Sustainable Use of Cultivated and Wild Tropical Fruit Diversity: Promoting Sustainable Livelihoods, Food Security and Ecosystem Services" started in 2009 at six sites. Two sites in Peninsular Malaysia were located at Yan, Kedah $\left(5.48^{\circ} \mathrm{N} 100.22^{\circ} \mathrm{E}\right)$ and Bukit Gantang, Perak $\left(4.47^{\circ} \mathrm{N} 100.46^{\circ} \mathrm{E}\right)$. The other two sites were from Sabah which at Papar $\left(5.73^{\circ} \mathrm{N}, 115.93^{\circ} \mathrm{E}\right)$ and Kota Belud $\left(6.21^{\circ} \mathrm{N} 116.26^{\circ} \mathrm{E}\right)$ and another two sites were from Sarawak which at Serian $\left(1.17^{\circ} \mathrm{N} 110.56^{\circ} \mathrm{E}\right)$ and Sibuti $\left(4.06^{\circ} \mathrm{N} 13.8^{\circ} \mathrm{E}\right)$.

\subsection{Public Awareness}

To increase public awareness in the community, diversity fruit fair was conducted during the fruiting season at all the project sites. Farmers and the community displayed all the fruits available in the home gardens and orchards. The fruits were labeled and presented to the public. The diversity of Mangifera, Garcinia and Nephelium species were documented and prepared into fruit catalogues. The fruit catalogue afterwards was given to the leader of the community at all sites to keep as their "community biodiversity register" references.

\subsection{Traditional Knowledge}

Interview was conducted to farmers and community on their knowledge regarding the fruit trees management and practices also others related to the fruit trees. The knowledge were later be taught to others in the community or used for further research. These local communities lived in the areas where the vast majority of the world's genetic resources are found. Many of them have cultivated and used biological diversity in a sustainable way for thousands of years. Some of their practices have been proven to enhance and promote biodiversity at the local 
level and aid in maintaining healthy ecosystems. As on-site communities with extensive knowledge of local environments, local communities are most directly involved with conservation and sustainable use.

\subsection{Utilization of Fruit Trees}

The utilization and commercialization of indigenous tropical fruit trees play a major role in contributing to the rural livelihoods. Tropical fruit trees are commonly seasonal in fruiting. To diversify its uses, functional product from the fruit was being developed for the use of the community. Processing of the fruit into functional drink, dried fruit, jam, pickle and jelly can add value to the fruits.

\subsection{Community Contribution for Conservation}

Three types of conservation approaches contributed by the communities were implemented based on social interest of the community at the site. The three conservation approaches were as follows (Table 1):

Type 1: Diversity block

(Land planted with diversity of fruit trees)

Type 2: Heritage block

(Diversity block with old heritage trees)

Type 3: Home gardens, orchards and public places

The fruit tree species planted were for the genera Mangifera, Garcinia and Nephelium. The source of the fruit trees were either provided by Department of Agriculture (DOA) or Malaysian Agricultural Research and Development Institute (MARDI) and the farmers own seedlings.

\section{Results}

During the five year project, a total of 1550 fruit trees mainly from the genera Mangifera, Garcinia and Nephelium were planted in all the project sites. At Kampung Kakeng, Serian, Sarawak, a five hectre land was converted to a diversity block. One hundred and ten fruit trees comprising species from the genera Mangifera, Nephelium, Garcinia, Durio, Artocarpus, Anonna, and Musa were planted (Figure 1).

An orchard consisted of many species of old trees at Sibuti, Sarawak was identified as a heritage block for conservation and education purposes (Figure 2). Mangifera pentandra tree aged more than 100 years from the Heritage Block was used as a source of seeds for new plantings. Infrastructures such as footpaths were built and the trees were labelled. In Kota Belud, Sabah, a few binjai (Mangifera caesia) trees 50 - 100 years old were labelled as heritage fruit trees for public awareness as well as for conservation (Figure 3). Sixteen Garcinia forbesii or aroi-aroi seedlings were distributed and planted in Kampung Bungaliu and Kampung Pandasan for fruit trees planting.

While at other sites in Yan, Bukit Gantang and Papar, fruit trees were planted in a common block which is in the homegardens, orchards and public places such as playground compounds or near riversides (Figure 4). A total of 243 fruit trees comprising 77 Nephelium lappaceum (rambutan), 110 Garcinia mangostana (mangosteen) and 56 Mangifera indica (mango) plants were distributed and planted in 3 villages at Yan, Kedah. In Bukit Gantang, Perak, Garcinia atroviridis, also known as asam gelugur was selected for planting in home gardens and community fruit orchards. While in Papar, Sabah, aroi-aroi was chosen to be planted in home gardens, orchards and public areas. A total of 130 aroi-aroi seedlings were planted in Kampung Penampang Baru and Kampung Daingin, Papar.

Table 1. Role of community in community based conservation approaches.

\begin{tabular}{cccc}
\hline Site & Diversity block & \multicolumn{2}{c}{$\begin{array}{c}\text { Common block (home garden, } \\
\text { orchard, public places) }\end{array}$} \\
Serian & $\begin{array}{c}\text { Managed by community; diversity } \\
\text { from mardi and local planted }\end{array}$ & $\begin{array}{c}\text { Individual households } \\
\text { Sibuti }\end{array}$ \\
Kota Belud & - & Managed by the community & Individual households \\
Papar & - & Managed by the community & Individual households \\
Yan & - & - & Individual households \\
Bukit Gantang & - & - & Individual households \\
\hline
\end{tabular}




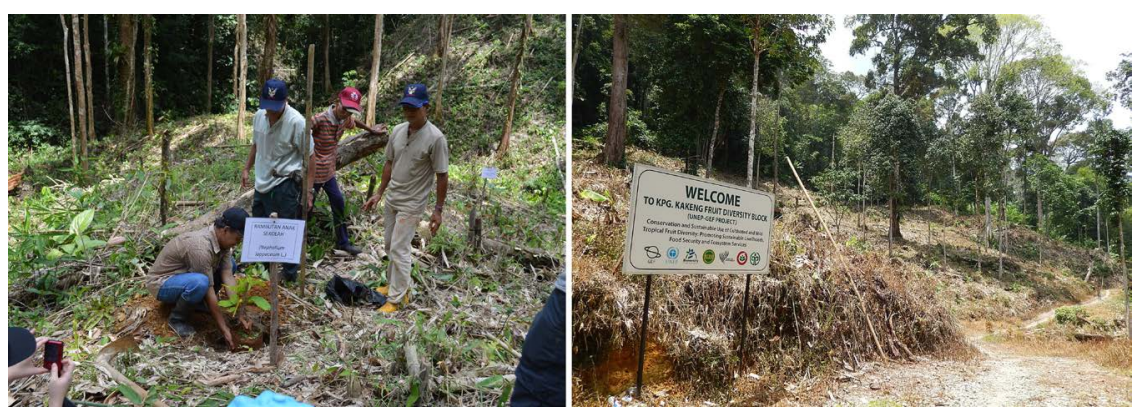

Figure 1. Diversity block in Kg. Kakeng, Serian, Sarawak.

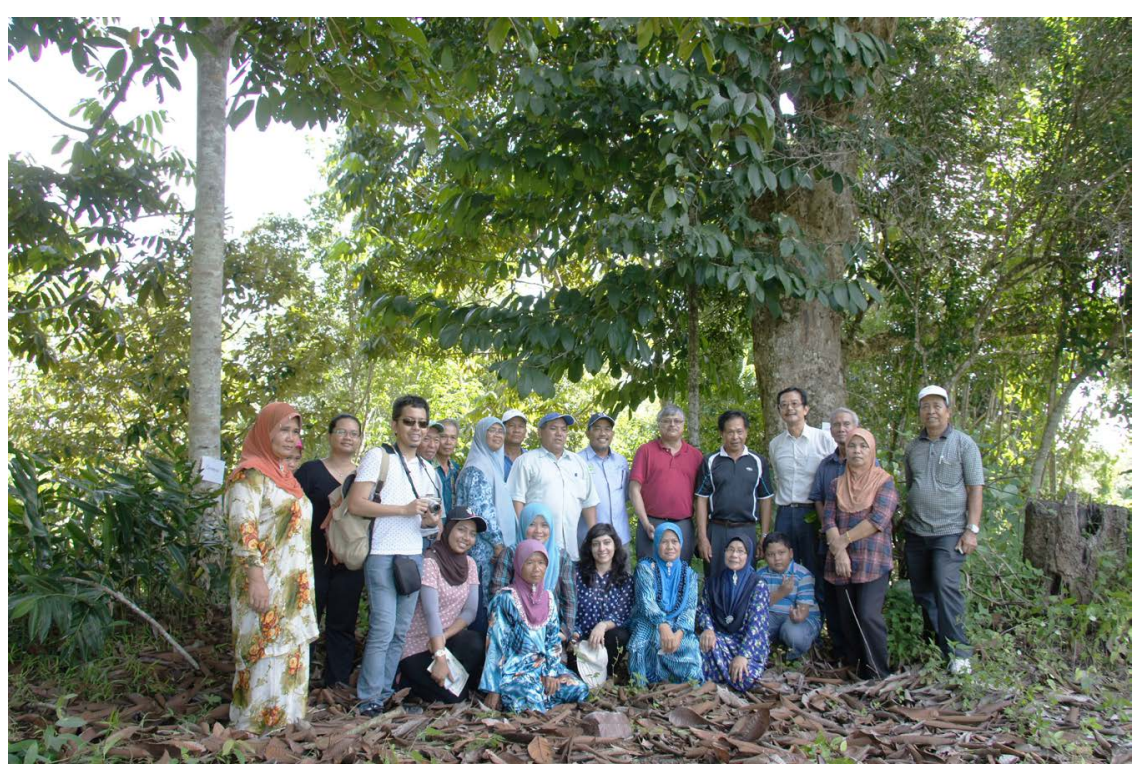

Figure 2. Heritage block in Kota Belud, Sabah.

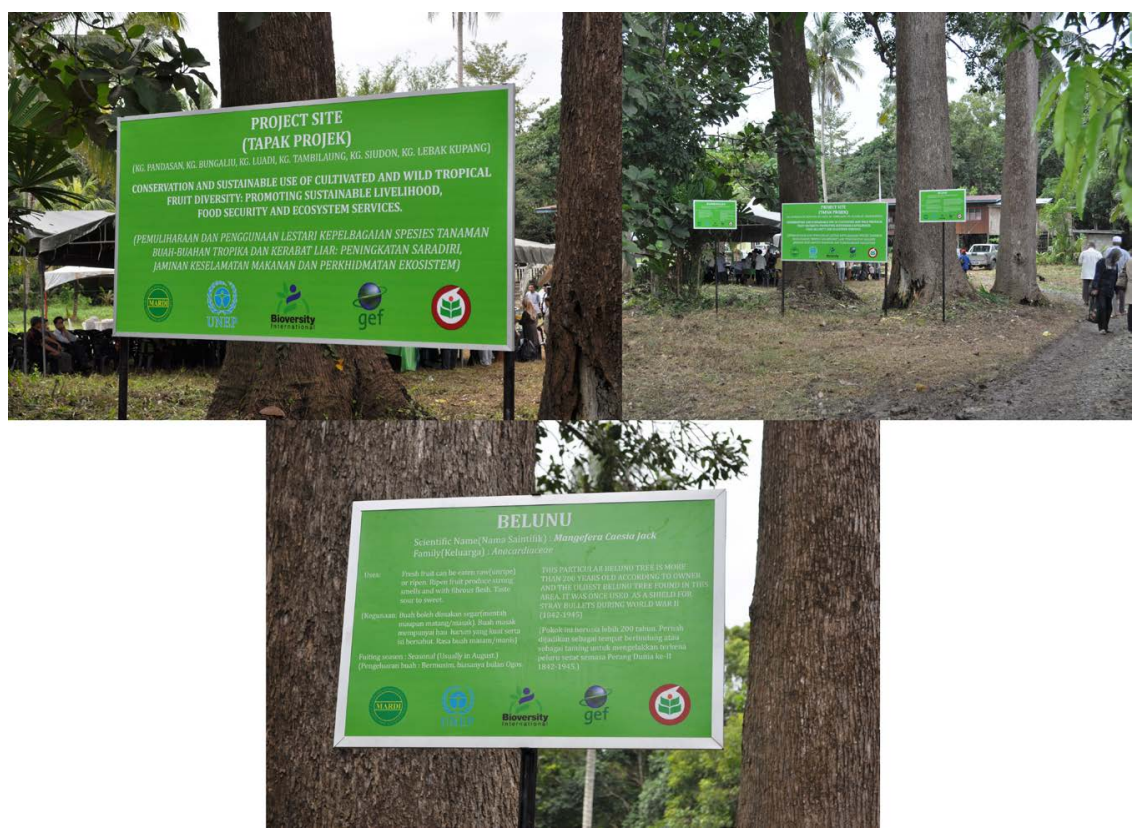

Figure 3. Historical trees were labeled in the heritage block. 


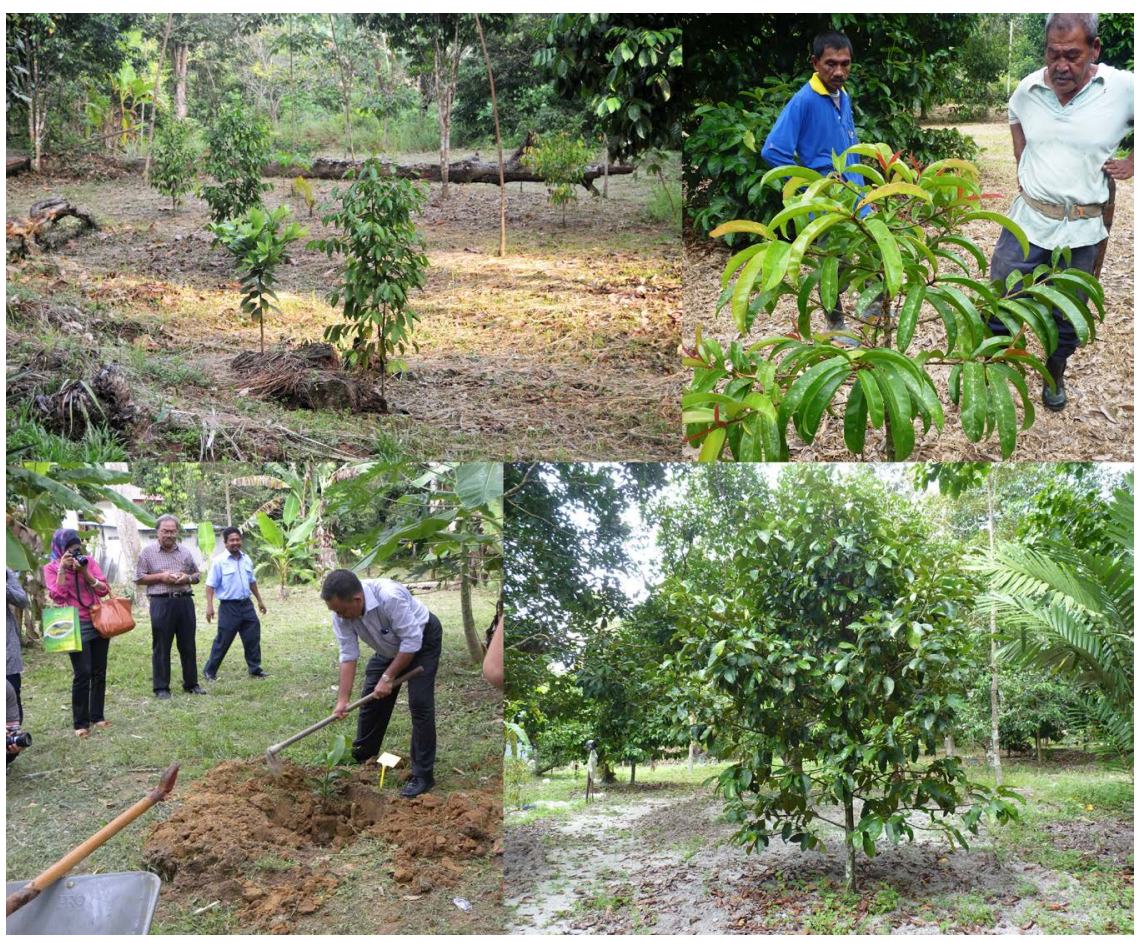

Figure 4. Planting of fruit trees in home gardens, orchards and public places.

These conservation activities compliment the ex-situ conservation carried out by the various government agencies. Fruit trees conserved in their ecological niches also provide ecosystem services.

\section{Discussion}

In-situ or on-farm conservation of tropical fruit trees is defined as a management of diverse set of fruit trees populations by the farmers or community in the ecosystem where the plant evolved. It allows for the process of evolution and adaptation of plants to their natural environment. Sustainable in-situ conservation is possible only when farmers, communities and national institutions perceive benefits in terms of genetic, economic, social and ecological aspects. These benefits grow in terms of private utility benefits and public benefits. In Nepal, the project "Enhancing contribution of home gardens to on-farm management of plant genetic resources and to improve livelihoods of Nepalese farmers" has increased areas producing socio-culturally important crops. This has been achieved through value addition of products and links to markets [5].

Diversity fruit fair was organized at all project sites to create awareness among the communities for conservation and promote utilization and consumption of tropical fruits. The exhibition was carried out with the participation from farmers and members of the community. They gathered all the fruits available from their garden and farm for display. From this fruit fair, farmers and the community will feel appreciated and build up their interest to conserve the fruit trees.

Training programs on grafting and pruning for fruit trees were also conducted at the sites. As a result, a community's nursery run by farmers was able to produce planting materials from elite trees found growing at the site for distribution to other communities. Besides that, trainings on Trigona bees rearing for flower pollination and fruit product development by women's group were also organized for the community to support tropical fruit tree genetic resources conservation and use. With all these trainings and awareness programmes, community and farmers would preserve the fruit trees they have had and at the same time provided side income and food source for the family.

Traditional knowledge documentation of the tropical fruit trees is useful in sharing knowledge of fruit production, medicinal uses and enhancing farmer's income. Some communities depend on their traditional knowledge for survival. Traditional knowledge usually has been orally passed for generations from father to son and so on. Some forms of traditional knowledge are expressed through stories, recipes, activities, legends, folklore, 
rituals, songs, and even laws [6]. Such knowledge is useful in developing appropriate research and development strategies on target fruit tree species. Farmers will conserve fruit trees if they find greater use of these tropical fruit trees.

The farmers and community implemented the conservation approaches based on the social interest. Salma et al. (2014) [7] described four types of conservation approach by the community. However, in this paper only three conservation approaches were explained. The diversity block was planted with three focus genera of plant on the land area identified by the community, which is near the forest and the community land. Thus, farmers and the community have the access to maintain and look after the fruit trees. When the fruiting season come, the diversity block can be an attraction and supported the ecotourism activity developed in the village. The trail built to connect the village and the diversity block can also used for jungle tracking activity by the tourist.

Diversity blocks with the old fruit trees planted by their ancestors were identified as a heritage block. Among these old trees, a few can be marked as elite trees based on their traits and performance. In order to promote the use of diversity in the orchards and home gardens, assessment of tropical fruit diversity was considered important. The elite lines identified in fruit species can be propagated at the nursery and distributed to other communities. While, trees of interest to specific farmers are planted in the home gardens, orchards and public areas. This practice has been applied by farmers at all sites.

A few custodian farmers who maintain high diversity of fruit species were self motivated and well regarded in the community for their on farm conservation effort. These conservation activities will compliment the ex situ conservation carried out by the various government agencies.

\section{Conclusion}

There is an urgent need to develop and upscale successful strategies to conserve both cultivated and wild relatives of tropical fruit species in Malaysia for economic, cultural, and ecological reasons. Three types of conservation approaches were adapted in this project. There were diversity block, heritage block and home garden. Increasing diversity of fruits in home gardens is a sustainable way to ensure quality food, dietary diversity and nutrition, particularly for vulnerable groups such as children, women and the elderly. With time, changes can be seen on community's attitude towards conservation when they realized the important role of tropical fruit trees.

\section{Recommendation}

To help conserve the fruit trees, farmers will need recognition for their effort, more used and products for income generation have to be developed.

\section{Acknowledgements}

This project was funded by the UNEP/GEF supported regional project "Conservation and Sustainable Use of Cultivated and Wild Tropical Fruit Diversity: Promoting Sustainable Livelihoods, Food Security and Ecosystem Services".

\section{References}

[1] Rhett, A.B. (2013) Malaysia Has the World's Highest Deforestation Rate, Reveals Google Forest Map. http://news.mongabay.com/2013/1115-worls-highest-deforestation-rate.html.

[2] Bhagmal, Ramanatha Rao, V., Arora, R.K., Percy, E. and Sajise, S.B.R. (2010) Conservation and Sustainable Use of Tropical Fruit Species Diversity: Bioversity’s Efforts in Asia, the Pacific and Oceania. Indian Journal Plant Genetic Resources, 24, 1-22.

[3] Sthapit, B., Ramanatha, R.V. and Sthapit, S. (2012) Tropical Fruit Tree Species and Climate Change. Bioversity International, New Delhi.

[4] Anegbeh, P.O., Tchoundjeu, Z., Anuforom, B.C., Ukafor, V. and Usoro, C. (2004) Farmers’ Participation in Ex-Situ Conservation of Indigenous Fruit Trees in Southern Nigeria. Journal of Agriculture and Social Research, 4, 33-42.

[5] Sthapit, B.R., Subedi, A., Gyawali, S., Jarvis, D. and Upadhaya, M.P. (2003) In Situ Conservation of Agricultural Biodiversity through Participatory Plant Breeding in Nepal.. In: Conservation and Sustainable Use of Agricultural Biodiversity: A Source Book Vol II: Strengthening Local Management of Agricultural Biodiversity. International Potato Centre (CIP) and User's Perspectives with Agricultural Research and Development (UPWARD), Los Banos, 311-321. 
[6] Acharya, D. and Shrivastava, A. (2008) Indigenous Herbal Medicines: Tribal Formulations and Traditional Herbal Practices. Aavishkar Publishers Distributor, Jaipur, 440.

[7] Salma, I., Muhammad Shafie, M.S., Shariah, U., Pearlycia, B., Wong, W.W., Shukor, A., Norhayati, H, Mohd Norfaizal, G. and Adam Haris, G.A. (2014) Community's Participation in the Conservation of Tropical Fruit Trees. The Proceeding of Agrobiodiversity and Agroenvironment Symposium, Kuching, 15-18 September 2014. 